\title{
Dynamic Mechanical and Thermal Behavior Analysis of Composites Based on Polypropylene Recycled with Vegetal Leaves
}

\author{
Cheila Gonçalves Mothé, Daniel Felipe J. Monteiro, Michelle Gonçalves Mothé \\ School of Chemistry, Federal University of Rio de Janeiro, Rio de Janeiro, Brazil \\ Email:cheila@eq.ufrj.br, danielmonteiro@ufrj.br,michelle@eq.ufrj.br
}

Received 15 June 2016; accepted 10 July 2016; published 13 July 2016

Copyright (C) 2016 by authors and Scientific Research Publishing Inc.

This work is licensed under the Creative Commons Attribution International License (CC BY). http://creativecommons.org/licenses/by/4.0/

c) (i) Open Access

\section{Abstract}

Thermal properties, as well as the dynamic mechanical behavior of recycled polypropylene composites with vegetal leaves contents, were studied by thermal analysis techniques: TG/DTG, DTA, and DMA. Composites made of polypropylene recycled with $1 \%, 5 \%, 10 \%$, and $15 \% w^{-1}$ vegetal leaves were prepared using the melt blending technique. The results revealed that the viscoelastic properties were influenced by fiber content; however, the glass transition temperature $\left(T_{g}\right)$ of the composite did not show significant changes to the fiber content. In the end, the composite with $\mathbf{5 \%}$ of palm leaves and PP recycled presented the most promising results since this one kept the solid characteristic on the dynamic mechanical properties. This work presents an environmental friendly alternative to manage natural waste, also being a form of reducing polymeric materials waste.

\section{Keywords}

Composites, Polypropylene, Palm Leaves, Thermal Analysis

\section{Introduction}

In recent decades the scientific community has been searching for sustainable ways to move forward. Thus, researches into finding solutions to waste generation, as well as to materials that reduce environmental impact, have been widely published [1]-[5]. Synthetic polymers have become a very important material since they are widely used in agriculture, industry, and technology [6]. However, most synthetic polymers have been developed from raw materials derived from petroleum and coal, which are not environmentally friendly [6] [7]. The search for sustainability provided an intense research on the replacement of synthetic materials by natural mate- 
rials, such as wood, fibers, and leaves in polymeric matrix composites [5] [8]. Suitable polymeric materials to be reinforced with vegetable fibers are thermoplastic resins and polyolefins, such as polyethylene (PE) and polypropylene (PP) [1]. Economic advantages, such as low prices and simple recycling processes, in addition to its suitable thermal stability, make PP a good composite matrix [1] [5] [6]. Despite the environmental appeal, some specific characteristics, such as low density, the ability to improve its hardness, high resistance to fatigue and corrosion, choice of fiber orientation, and the variety of combinations of fibers and matrices, make the natural fiber reinforced polymer composites an interesting material class [8]-[11].

The viscoelastic properties evaluation of new polymeric composites allows for analysis of their storage capacity and energy dissipation during mechanical effort. In fact, the DMA technique is useful for evaluating viscoelasticity behavior of composites reinforced with vegetable fibers, with important contributions to chemical structures, and data about glass transition and crystallization point [4]. The DMA technique has been widely used to calculate storage modulus $\left(E^{\prime}\right)$, loss modulus $\left(E^{\prime \prime}\right)$, and loss factor $(\tan \delta)$ [1] [3] [5] [9].

Many studies have been performed around the globe studying different contributions that natural fibers could bring to synthetic polymers to improve mechanical, thermal, physical properties in new composites.

Garcia-Garcia et al. (2015) performed a valuable thermal and mechanical study about the influence on hydrophobized vegetal powder on a polypropylene matrix. There was an increase in thermal stability on the composites observed by thermogravimetric curves over $450^{\circ} \mathrm{C}$ with the addiction on these coffee ground powder [12].

Jeencham et al. (2014) suggested that adding different flame retardants into sisal fibre/PP composites increased thermal stability and flame retardance [13].

Kumar and Rajendra (2014) developed a composite using polypropylene and defatted horn fibre. It was studied mechanical and physical properties, such as tensile, elongation, flexural strength and others. Comparing to PP pure most of the mechanical properties were improved [14].

Essabir et al. (2013) performed a study using PP composites with almond shells with and without compatibilizer agents. Results exhibited that composites without compatibilizer showed better mechanical properties [15].

Parparita et al. (2014) evaluated different types of biomass in PP composites without any compatibilizer agent. Experimental data showed that the Eucalyptus globulus sawdust was the biomass that had the most positive effect on crystallinity if compared with PP neat [16].

The aim of this work is to study the thermal and dynamic mechanical properties of a new composite material obtained from polypropylene recycled neat reinforced with natural fibers of palm leaves, developed as a sustainable solution for waste management. One of the innovative proposal of this work is to prepare composites without previous chemical treatment or adding compatibilizer agent.

\section{Experimental}

\subsection{Materials}

The polymeric material used for the composite matrix was polypropylene recycled neat (PP) obtained by grinding polypropylene cups discarded, already used, from the university restaurant. The reinforcement was made from vegetable fibers obtained byfrom the milling of vegetal palm leaves waste, which had fallen from palm trees (Syagrus romanzoffiana), in the university campus of Rio de Janeiro, Brazil. Some authors [17]-[20] proposed an alkaline wash with a $5 \% \mathrm{ww}^{-1} \mathrm{NaOH}$ aqueous solution to eliminate impurities and to decrease the content of lignin and hemicellulose from the natural fibers. However, recent work [16] and [21] seems to have obtained good results without the alkalizing treatment, favoring an environmental friendly practicewithout the production of alkaline wastes. Thus, the raw materials were washed with distilled water and then dried. The PP recycled was dried at room temperature, and the leaves were dried in an oven at $40^{\circ} \mathrm{C}$, both for $24 \mathrm{~h}$.

\subsection{Composite Preparation}

After washing and drying the raw materials, polypropylene recycled cups and vegetal palm leaves waste were milled in a LP1003 Primotecnica mill. Composites were obtained from melt mixing technique in a Haake mixer polylab QC, Thermo Scientific, with different quantities of palm leaves: $1 \%, 5 \%, 10 \%$, and $15 \% \mathrm{ww}^{-1}$. The raw materials were mixed and processed for 8 minutes at $200^{\circ} \mathrm{C}$. The samples were obtained from compression at a Carver press with 12 ton at $200^{\circ} \mathrm{C}$ for 5 minutes. Five samples were obtained in this work: PP recycled neat, PP recycled $+1 \% \mathrm{ww}^{-1}$ palm leaves; PP recycled $+5 \% \mathrm{ww}^{-1}$ palm leaves; PP recycled $+10 \% \mathrm{ww}^{-1}$ palm leaves; 
and PP recycled $+15 \% \mathrm{ww}^{-1}$ palm leaves; and they were denominated as PP recycled; PP recycled $/ 1$ palm; PP recycled/5 palm; PP recycled/10 palm; PP recycled/15 palm, respectively. It is relevant to mention that polypropylene control in this work will be the matrix used to develop the composites, which is the polypropylene recycled neat. Polypropylene virgin was not an interest of study of in this present work.

\subsection{Methods}

Thermal characterization of all composites by Thermogravimetry, Derivative Thermogravimetry (TG/DTG) and Differential Thermal Analysis (DTA) experiments were carried out on TA Instruments, SDT Q600 model, at heating rate of $10^{\circ} \mathrm{C} \cdot \mathrm{min}^{-1}$, under nitrogen atmosphere. Sample sizes were $5 \mathrm{mg}$ with a flow rate of $120 \mathrm{ml} \cdot \mathrm{min}^{-1}$ and over a temperature range from room temperature to $800^{\circ} \mathrm{C}$.

The DMA (Dynamic Mechanical Analysis) of the composites obtained was performed in equipment by TA Instruments, model DMA Q800, at heating rate of $3^{\circ} \mathrm{C} \mathrm{min}^{-1}$, frequency of $1 \mathrm{~Hz}$, and strain $0.1 \%$ at temperature ranging from -40 to $150^{\circ} \mathrm{C}$. Samples with dimensions of $37 \times 13 \times 2 \mathrm{~mm}$ were prepared and used for this analysis.

\section{Results and Discussion}

Figure 1 shows a comparison of thermogravimetry (TG) curves for palm leaves, PP recycled neat, and composites (recycled PP $+1 \%, 5 \%, 10 \%$ and $15 \% \mathrm{ww}^{-1}$ palm leaves content). Two decomposition stages can be seen in the palm leaves' degradation. The first stage from $25^{\circ} \mathrm{C}$ to $100^{\circ} \mathrm{C}$ is related to humidity, and the second stage at $200^{\circ} \mathrm{C}$ to $380^{\circ} \mathrm{C}$, due to the decomposition of cellulose, hemicellulose, and lignin [8] [22]. All composites with different palm leaves content, also present two decomposition stages. The first stage from $230^{\circ} \mathrm{C}$ to $418^{\circ} \mathrm{C}$, related to decomposition of lignocellulosic components [8] [22], and the second stage from $403^{\circ} \mathrm{C}$ to $484^{\circ} \mathrm{C}$, due to the polymer matrix decomposition samples, while PP recycled neat exhibited a decomposition stage from $400^{\circ} \mathrm{C}$ to $484^{\circ} \mathrm{C}$. However, it is possible to observe that the composite with $15 \% \mathrm{ww}^{-1}$ of palm leaves showed the highest amount residue at $800^{\circ} \mathrm{C}$.

The comparison of derivative thermogravimetry (DTG) curves in Figure 2 depict a major degradation stage

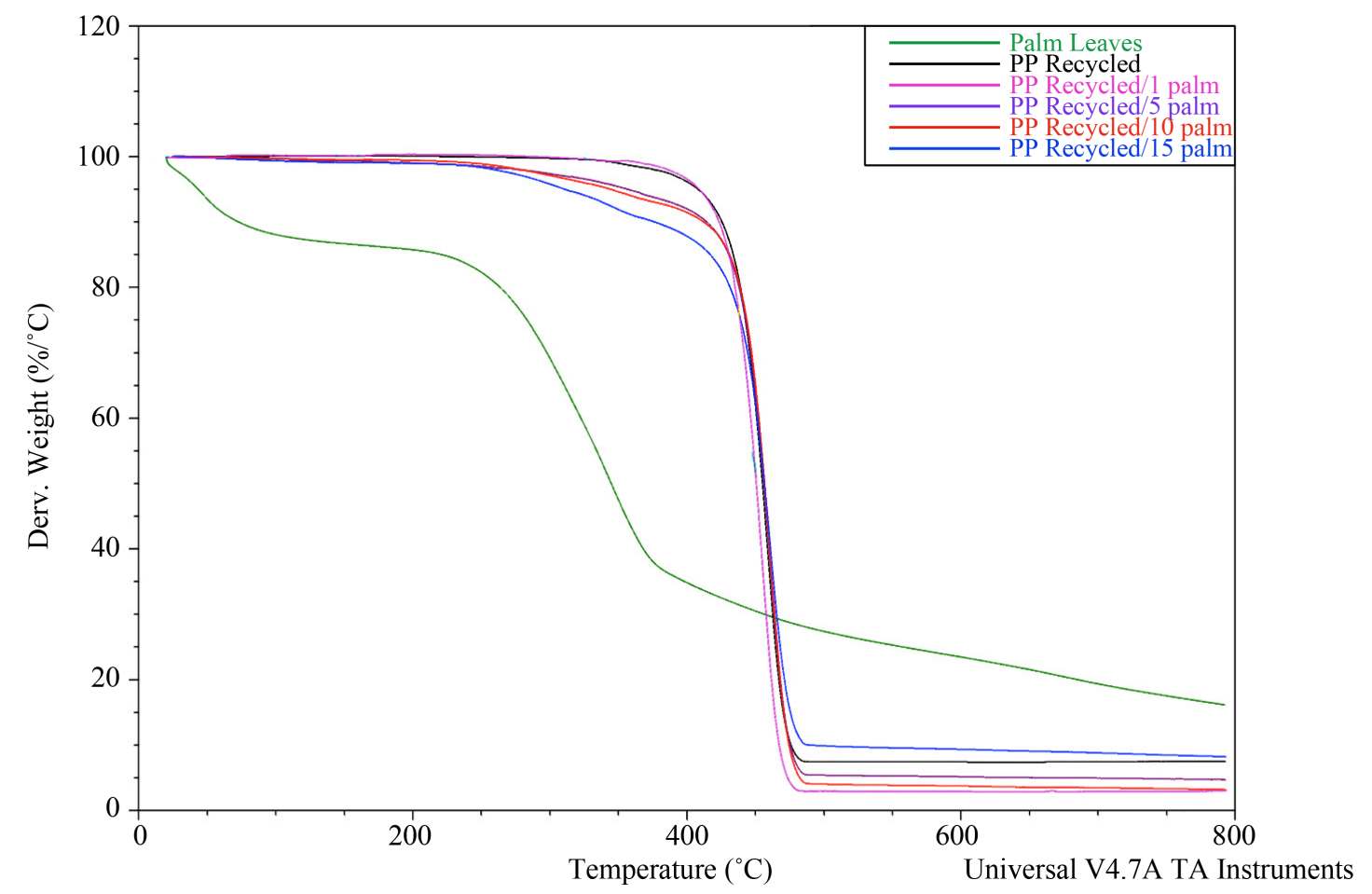

Figure 1. Comparison of TG curves of palm leaves, recycled PP and composites with PP recycled + 1, 5, 10 and 15 palm. 


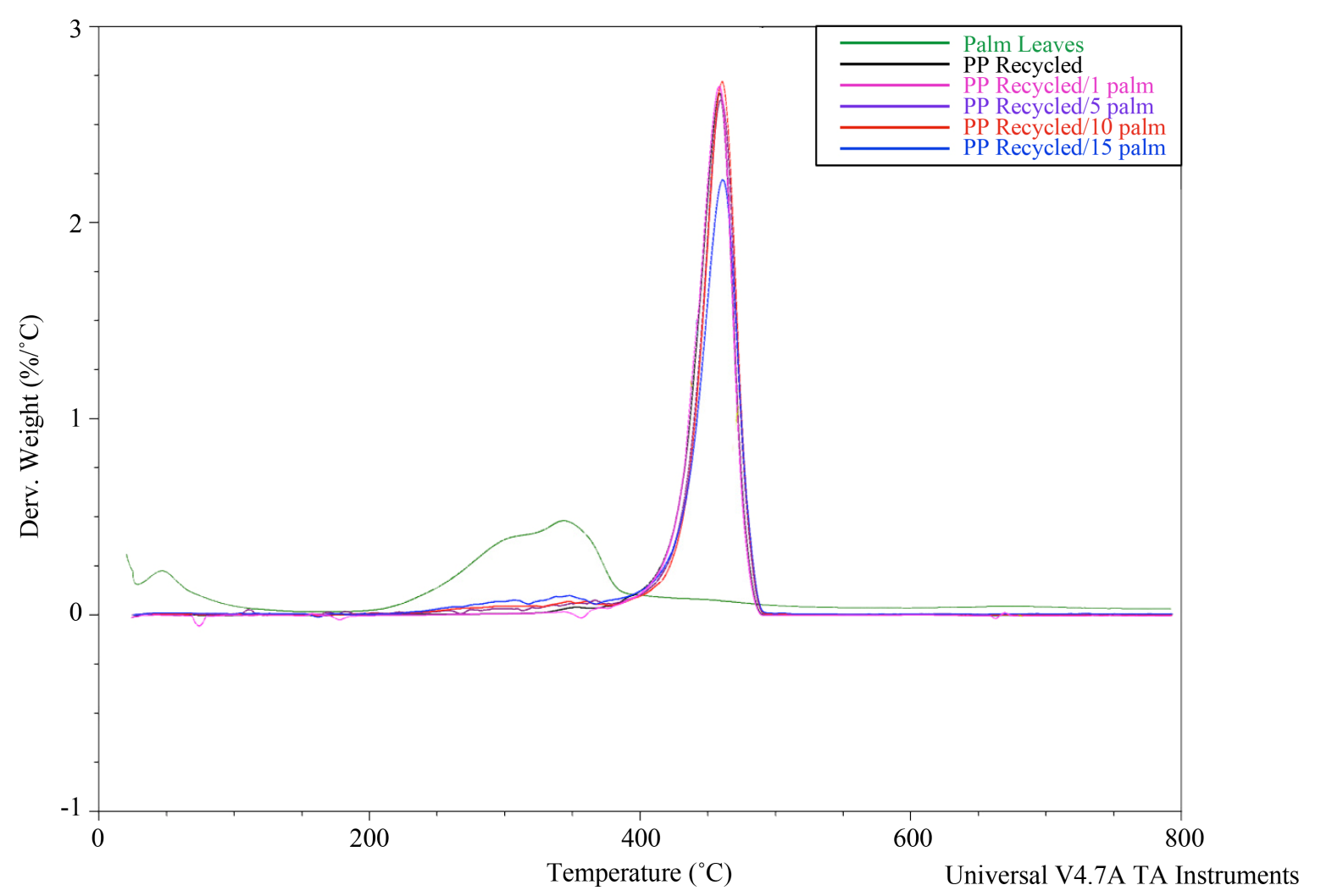

Figure 2. Comparison of DTG curves of palm leaves, recycled PP and composites with PP recycled + 1, 5, 10 and 15 palm.

around $460^{\circ} \mathrm{C}$, for PP recycled and its composites. However, DTG curve forpalm leaves sample exhibited two peaks of decomposition at $47^{\circ} \mathrm{C}$ and $345^{\circ} \mathrm{C}$. The first peak is related to the humidity and the second peak refers to the main decomposition of cellulose, hemicellulose, and lignin [8] [22] [23].

The Differential Thermal Analysis (DTA) curves in Figure 3 for the three composites and for the recycled PP, exhibit the presence of two endothermic events at both around $160^{\circ} \mathrm{C}$ and $460^{\circ} \mathrm{C}$, referring to polypropylene melting temperature $\left(T_{m}\right)$ and its decomposition. All composites depict these events related with their polymeric matrix. The palm leaves sample presented two endothermic events at both around $50^{\circ} \mathrm{C}$ and $350^{\circ} \mathrm{C}$, suggesting humidity and decomposition of cellulose and lignin. A summary including all the decomposition stages and thermal events for the palm leaves, recycled PP and its composites are illustrated in Table 1.

The Dynamic Mechanical Analysis allows for obtaining the storage modulus $\left(E^{\prime}\right)$, loss modulus $\left(E^{\prime \prime}\right)$, and tangent delta $(\tan \delta)$ curves. Table 2 shows the results obtained from the curves shown in Figures 4-6.

Figure 4 illustrates the comparison of storage modulus versus temperature for the polypropylene recycled composites with palm leaves. At $25^{\circ} \mathrm{C}$, the PP recycled storage modulus $\left(E^{\prime}\right)$ was of $1375 \mathrm{MPa}$. The increase of reinforcement incorporation had lowered the elastic behavior effects. However, $1 \%$ and $5 \% \mathrm{ww}^{-1}$ palm leaves incorporation maintains the elastic solid behavior from PP recycled neat.

Figure 5 shows the comparison of loss modulus versus temperature for the recycled polypropylene composites with palm leaves. At $25^{\circ} \mathrm{C}$, the PP recycled reinforced with $15 \% \mathrm{ww}^{-1}$ palm leaves showed the lower loss modulus value ( $67 \mathrm{MPa})$.

The tangent delta curves $(\tan \delta)$ in Figure 6 allowed for the observation of a peak between $0^{\circ} \mathrm{C}$ and $20^{\circ} \mathrm{C}$ assigned to the glass transition temperature $\left(T_{g}\right)$. The peaks presented in Figure 5 also refer to polymer $T_{g}$. In fact, the glass transition temperatures values obtained for both tan delta and loss modulus curves were relatively close to each other, with difference of no greater than $7^{\circ} \mathrm{C}$. Thus, the values obtained for $T_{g}$ were similar to composites with different amount of leaves, indicating that they were not composite's mobility were not damage by the vegetal leaves incorporation.

As shown in Table 2, the loss modulus values at $25^{\circ} \mathrm{C}$ are the same till $5 \%$ of palm leaves incorporation as the 


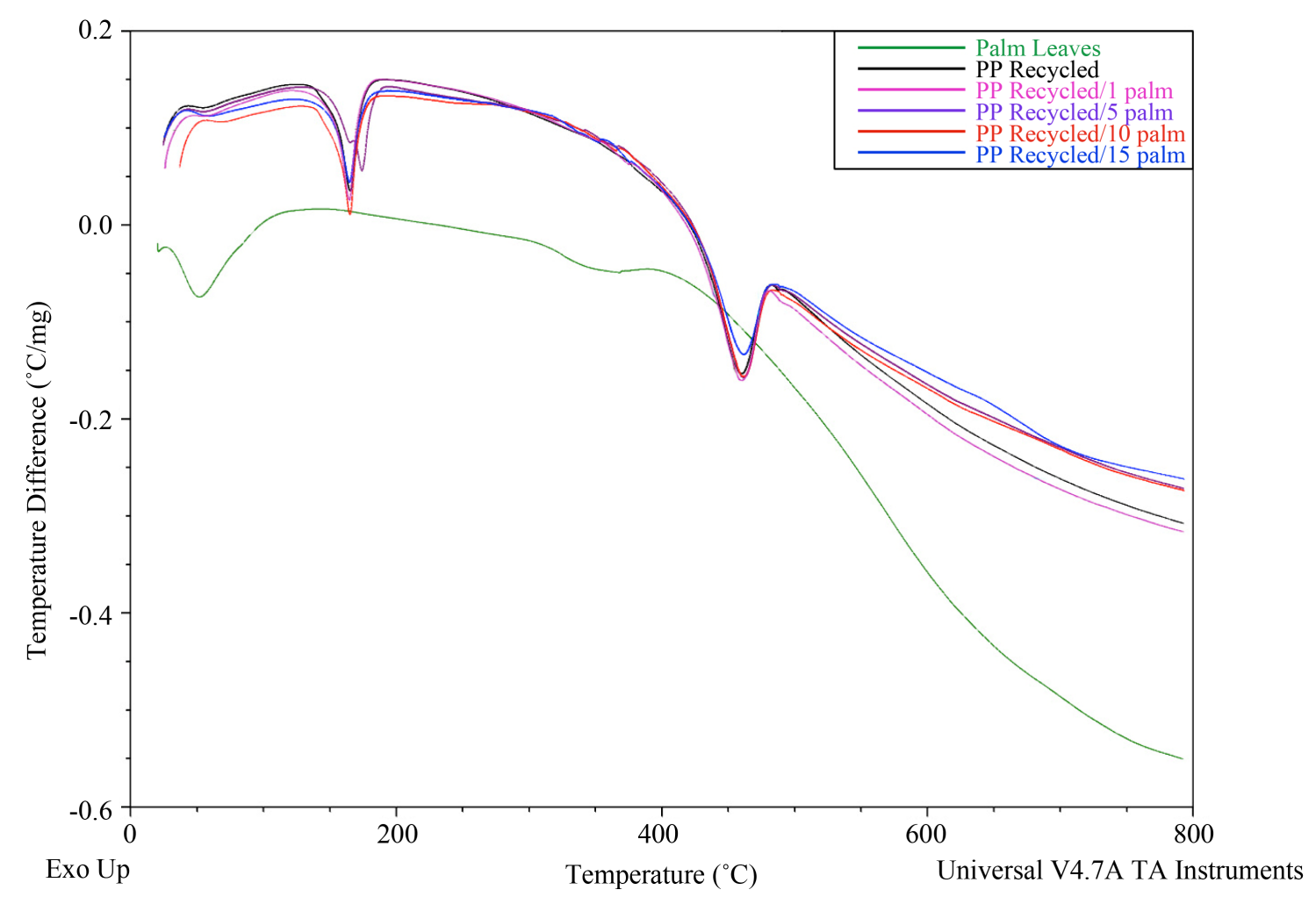

Figure 3. Comparison of DTA curves of palm leaves, recycled PP and composites with PP recycled + 1, 5, 10 and 15 palm.

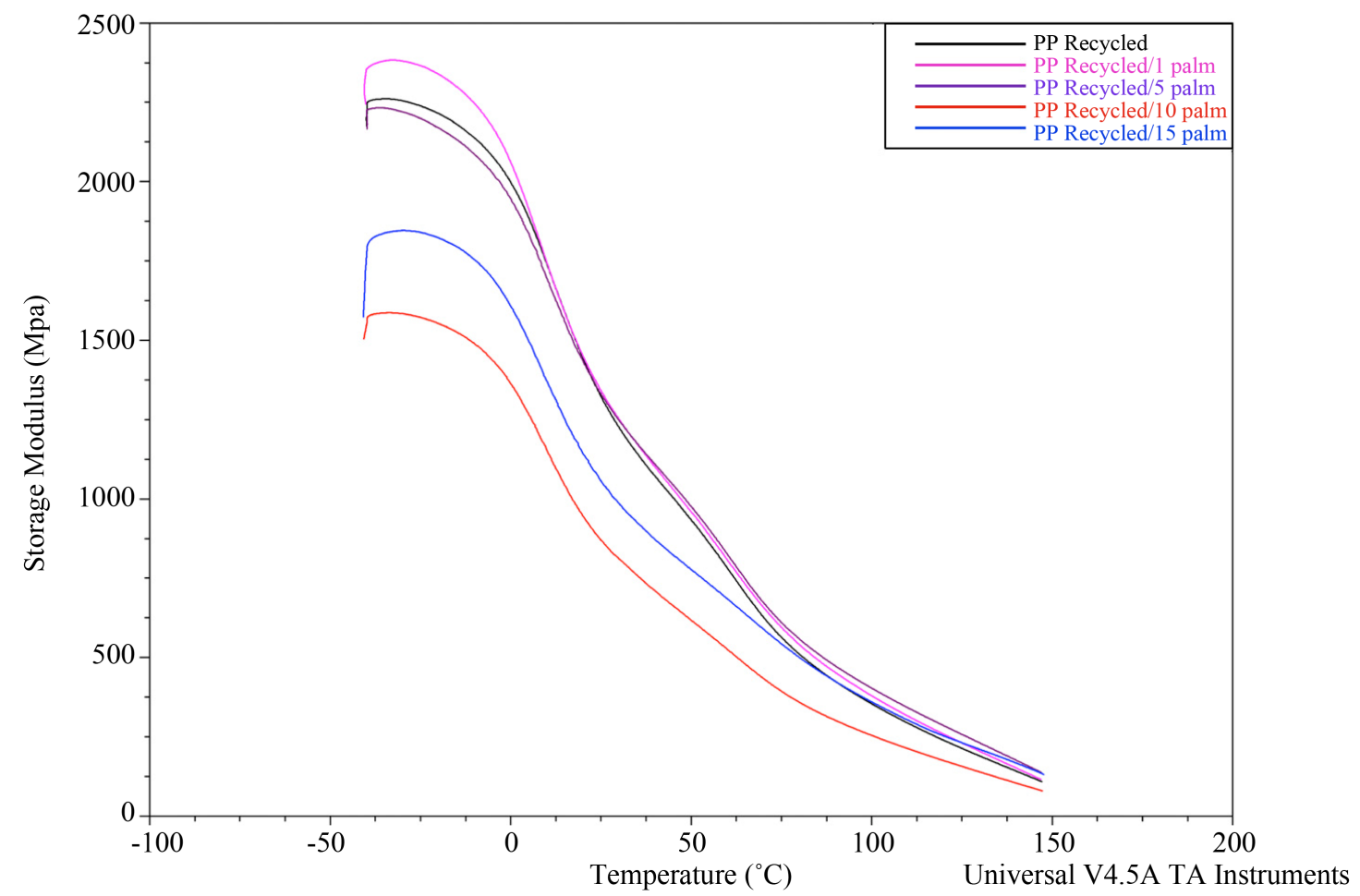

Figure 4. Comparison of storage modulus $\left(E^{\prime}\right)$ versus temperature curves for PP recycled and its composites with 1 , 5, 10 and 15 palm. 


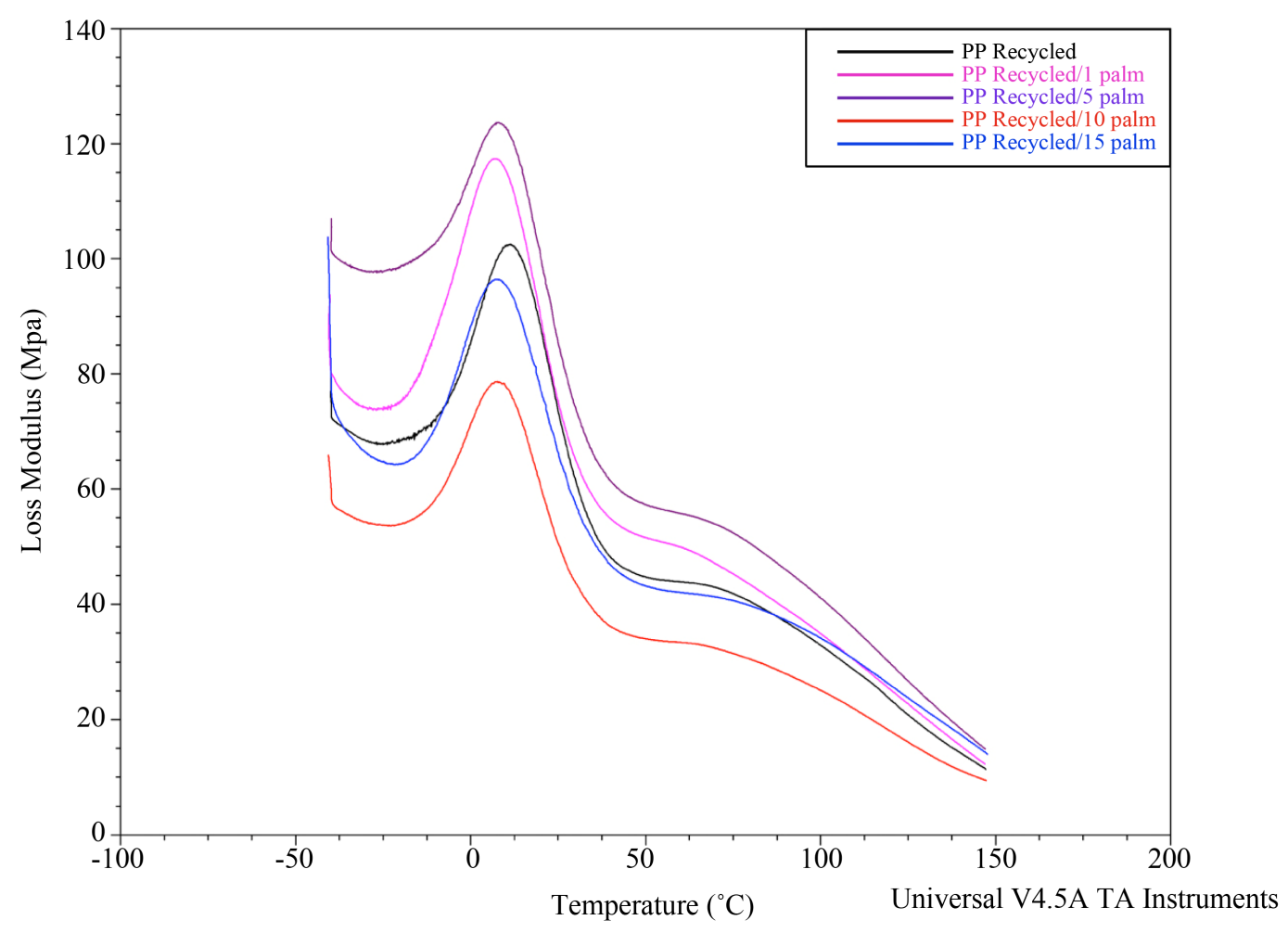

Figure 5. Comparison of loss modulus $\left(E^{\prime \prime}\right)$ versus temperature curves for PP recycled and its composites with $1,5,10$ and 15 palm.

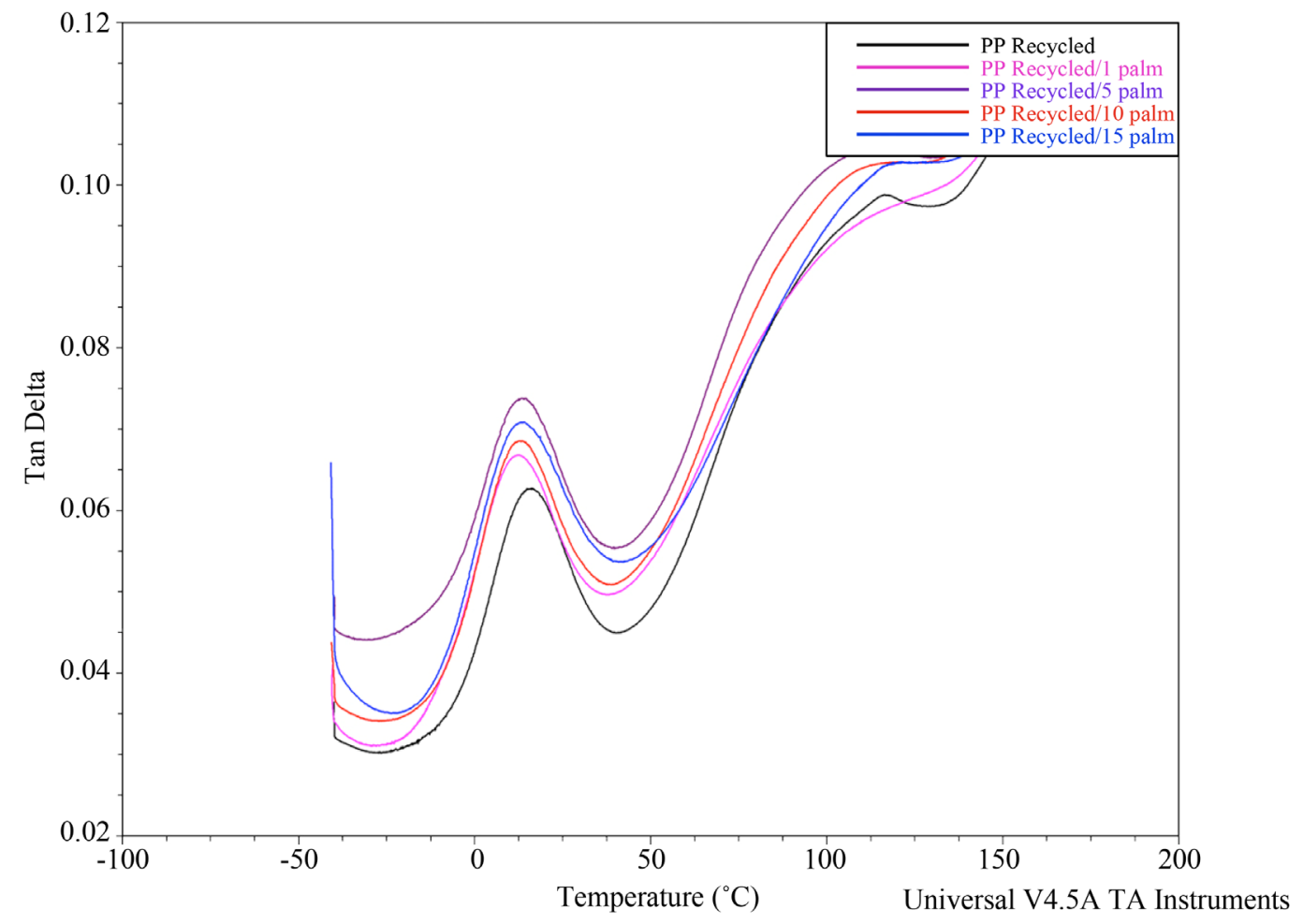

Figure 6. Comparison of $\tan \delta$ versus temperature curves for PP recycled and its composites with 1, 5, 10 and 15 palm. 
Table 1. Summary of TG/DTG and DTA analysis for palm leaves, PP recycled neat and its composites.

\begin{tabular}{|c|c|c|c|c|c|c|}
\hline Samples & $\begin{array}{c}T_{\text {initial }}\left({ }^{\circ} \mathrm{C}\right) \\
\text { TG }\end{array}$ & $\mathrm{TFD}^{\mathrm{a}}\left({ }^{\circ} \mathrm{C}\right) \mathrm{TG}$ & Mass loss \% TG & $\begin{array}{c}T_{\text {peak }}\left({ }^{\circ} \mathrm{C}\right) \\
\text { DTG }\end{array}$ & $\begin{array}{c}\text { Endo Events }\left({ }^{\circ} \mathrm{C}\right) \\
\text { DTA }\end{array}$ & Residue at $800^{\circ} \mathrm{C} \% \mathrm{TG}$ \\
\hline Palm & 25 & 80 & 12 & 47 & 51 & 16 \\
\hline Leaves & 200 & 380 & 50 & 345 & 346 & 16 \\
\hline $\begin{array}{c}\text { PP } \\
\text { Recycled }\end{array}$ & 300 & 482 & 92 & 461 & $\begin{array}{l}164 \\
461\end{array}$ & 8 \\
\hline $\begin{array}{l}\text { PP Recycled/ } \\
1 \text { palm }\end{array}$ & $\begin{array}{l}283 \\
403\end{array}$ & $\begin{array}{l}403 \\
482\end{array}$ & $\begin{array}{c}2 \\
92\end{array}$ & 461 & $\begin{array}{l}164 \\
461\end{array}$ & 3 \\
\hline $\begin{array}{l}\text { PP Recycled/ } \\
5 \text { palm }\end{array}$ & $\begin{array}{l}271 \\
416\end{array}$ & $\begin{array}{l}416 \\
484\end{array}$ & $\begin{array}{c}5 \\
85\end{array}$ & 461 & $\begin{array}{l}168 \\
461\end{array}$ & 5 \\
\hline $\begin{array}{l}\text { PP Recycled/ } \\
10 \text { palm }\end{array}$ & $\begin{array}{l}242 \\
416\end{array}$ & $\begin{array}{l}416 \\
482\end{array}$ & $\begin{array}{c}9 \\
86\end{array}$ & 461 & $\begin{array}{l}164 \\
461\end{array}$ & 3 \\
\hline $\begin{array}{l}\text { PP Recycled/ } \\
15 \text { palm }\end{array}$ & $\begin{array}{l}229 \\
418\end{array}$ & $\begin{array}{l}418 \\
482\end{array}$ & $\begin{array}{l}12 \\
75\end{array}$ & 461 & $\begin{array}{l}164 \\
461\end{array}$ & 9 \\
\hline
\end{tabular}

${ }^{\mathrm{a}}$ Final decomposition temperature.

Table 2. Storage modulus $\left(E^{\prime}\right)$ and loss modulus $\left(E^{\prime \prime}\right)$ values at $25^{\circ} \mathrm{C}$ and glasstransition $\left(T_{g}\right)$ values obtained for all samples.

\begin{tabular}{ccccc}
\hline Samples & $E^{\prime}(\mathrm{MPa})$ & $E^{\prime \prime}(\mathrm{MPa})$ & \multicolumn{2}{c}{$T_{g}\left({ }^{\circ} \mathrm{C}\right)$} \\
\cline { 4 - 5 } PPRecycled & 1321 & 73 & 11 & Tan delta \\
PP Recycled/1 palm & 1354 & 77 & 7 & 16 \\
PP Recycled/5 palm & 1354 & 86 & 8 & 13 \\
PP Recycled/10 palm & 869 & 51 & 8 & 13 \\
PP Recycled/15 palm & 1053 & 67 & 7 & 14 \\
\hline
\end{tabular}

PP recycled neat. Thus, this quantity of palm leaves indicates that is possible to incorporate on the PP composite and kept the solid characteristic on the material. Another information is that the order of magnitude of $E^{\prime}$ is 20 times higher than the $E$ " values for all of the samples studied.

\section{Conclusion}

This work presented the development and the study of a promising methodology to make a new environmental friendly composite material, being a sustainable alternative for solid waste management. It is worth mentioning that there are some interesting thermal and viscoelastic properties on these composites, which justifies the need to produce a green material from low cost, reducing the large amount of urban waste. In this way this manuscript has scientific relevance and technological innovation. Indeed, used cups made of polypropylene recycled and fallen palm leaves would otherwise be subject to waste. It was possible to obtain PP composites reinforced with different contents of palm leaves $\left(1 \%, 5 \%, 10 \%\right.$, and $\left.15 \% \mathrm{ww}^{-1}\right)$. Thermal analysis indicates that the composites kept the thermal stability, comparing to PP recycled neat. Moreover, the results of solid-elastic behavior showed that the glass transition temperature $\left(T_{g}\right)$ of the composite had not changed significantly as the vegetal leaves waste incorporation increased. Both methods to obtained $T_{g}$ from the tan delta and loss modulus curves had relatively close results. Finally, it is possible to point out that, according to TA results, the composite with $5 \%$ of palm leaves and PP recycled shows the most promising results as both storage and loss modulus are the close to the PP recycled neat, but mostly that it will be possible to incorporate till $5 \%$ of palm leaves, which means that it will be less amount of PP to be consumed.

\section{Acknowledgements}

The authors thank the Brazilian Council for Scientific and Technological Development (CNPq) for the financial 
support and the Laboratories of Thermal Analysis and Rheology from Federal University Rio de Janeiro/Brazil.

\section{References}

[1] Wielage, B., Lampke, Th., Utschick, H. and Soergel, F. (2003) Processing of Natural-Fibre Reinforced Polymers and the Resulting Dynamic-Mechanical Properties. Journal of Materials Processing Technology, 139, 140-146. http://dx.doi.org/10.1016/S0924-0136(03)00195-X

[2] Karaduman, Y., Sayeed, M.M.A., Onal, L. and Rawal, A. (2014) Viscoelastic Properties of Surface Modified Jute Fiber/Polypropylene Nonwoven Composites. Composites Part B: Engineering, 67, 111-118. http://dx.doi.org/10.1016/j.compositesb.2014.06.019

[3] Herrera-Franco, P.J. and Valadez-González, A. (2004) Mechanical Properties of Continuous Natural Fibre-Reinforced Polymer Composites. Composites Part A: Applied Science and Manufacturing, 35, 339-345. http://dx.doi.org/10.1016/j.compositesa.2003.09.012

[4] Cassu, S.N. and Felisberti, M.I. (2005) Comportamento dinâmico-mecânico e relaxações em polímeros e blendas poliméricas. Química Nova [Online], 28, 255-263. http://dx.doi.org/10.1590/S0100-40422005000200017

[5] Yousif, B. and El-Tayeb, N. (2007) Tribological Evaluations of Polyester Composites Considering Three Orientations of CSM Glass Fibres Using BOR Machine. Applied Composite Materials, 14, 105-116. http://dx.doi.org/10.1007/s10443-007-9034-2

[6] Al-Oqla, F.M. and Sapuam, S.M. (2014) Natural Fiber Reinforced Polymer Composites in Industrial Applications: Feasibility of Date Palm Fibers for Sustainable Automotive Industry. Journal of Cleaner Production, 66, 347-354. http://dx.doi.org/10.1016/j.jclepro.2013.10.050

[7] Ashori, A. and Nourbakhsh, A. (2009) Characteristics of Wood-Fiber Plastic Composites Made of Recycled Materials. Waste Management, 29, 1291-1295. http://dx.doi.org/10.1016/j.wasman.2008.09.012

[8] Stokke, D.D., Wu, Q. and Han, G. (2014) Introduction to Wood and Natural Fiber Composites. John Wiley \& Sons, UK, 649.

[9] Marinelli, A.L., Monteiro, M.R., Ambrósio, J.D., Branciforti, M.C., Kobayashi, M. and Nobre, A.D. (2008) Desenvolvimento de Compósitos Poliméricos com Fibras Vegetais Naturais da Biodiversidade: Uma Contribuição para a Sustentabilidade Amazônica. Polímeros, 18, 92-99. http://dx.doi.org/10.1590/S0104-14282008000200005

[10] Zampaloni, M., Pourboghrat, F., Yankovich, S.A., Rodgers, B.N., Moore, J., Drzal, L.T., Mohanty, A.K. and Misra, M. (2007) Kenaf Natural Fiber Reinforced Polypropylene Composites: A Discussion on Manufacturing Problems and Solutions. Composites Part A: Applied Science and Manufacturing, 38, 1569-1580. http://dx.doi.org/10.1016/j.compositesa.2007.01.001

[11] Dehghani, A., Madadi Ardekani, S., Al-Maadeed, M.A., Hassan, A. and Wahit, M.U. (2013) Mechanical and Thermal Properties of Date Palm Leaf Fiber Reinforced Recycled Poly(ethylene terephthalate) Composites. Materials \& Design, 52, 841-848. http://dx.doi.org/10.1016/j.matdes.2013.06.022

[12] García-García, D., Carbonell, A., Samper, M.D., García-Sanoguera, D. and Balart, R. (2015) Green Composites Based on Polypropylene Matrix and Hydrophobized Spend Coffee Ground (SCG) Powder. Composites Part B: Engineering, 78, 256-265. http://dx.doi.org/10.1016/j.compositesb.2015.03.080

[13] Jeencham, R., Suppakarn, N. and Jarukumjorn, K. (2014) Effect of Flame Retardants on Flame Retardant, Mechanical, and Thermal Properties of Sisal Fiber/Polypropylene Composites. Composites Part B: Engineering, 56, 249-253. http://dx.doi.org/10.1016/j.compositesb.2013.08.012

[14] Kumar, D. and Boopathy, S.R. (2014) Mechanical and Thermal Properties of Horn Fibre Reinforced Polypropylene Composites. Procedia Engineering, 97, 648-659. http://dx.doi.org/10.1016/j.proeng.2014.12.294

[15] Essabir, H., Nekhlaoui, S., Malha, M., Bensalah, M.O., Arrakhiz, F.Z., Qaiss, A. and Bouhfid, R. (2013) Bio-Composites Based on Polypropylene Reinforced with Almond Shells Particles: Mechanical and Thermal Properties. Materials and Design, 51, 225-230. http://dx.doi.org/10.1016/j.matdes.2013.04.031

[16] Parparita, E., Darie, R.N., Popescu, C.M., Uddin, A.M. and Vasile, C. (2014) Structure-Morphology-Mechanical Properties Relationship of Some Polypropylene/Lignocellulosic Composites. Materials and Design, 56, 763-772. http://dx.doi.org/10.1016/j.matdes.2013.12.033

[17] Azwa, Z.N., Yousif, B.F., Manalo, A.C. and Karunasena, W. (2013) A Review on the Degradability of Polymeric Composites Based on Natural Fibres. Materials and Design, 47, 424-442.

[18] Ray, D., Sarkar, B.K., Rana, A.K. and Bose, N.R. (2001) The Mechanical Properties of Vinylester Resin Matrix Composites Reinforced with Alkali-Treated Jute Fibers. Composites Part A: Applied Science and Manufacturing, 32, 119127. http://dx.doi.org/10.1016/S1359-835X(00)00101-9

[19] Huda, M.S., Drzal, L.T., Mohanty, A.K. and Misra, M. (2008) Effect of Chemical Modifications of the Pineapple leaf 
FIBER Surfaces on the Interfacial and Mechanical Properties of Laminated Biocomposites. Composite Interfaces, 15, 169-191. http://dx.doi.org/10.1163/156855408783810920

[20] Goda, K., Sreekala, M.S., Gomes, A., Kaji, T. and Ohgi, J. (2006) Improvement of Plant Based Natural Fibers for Toughening Green Composites-Effect of Load Application during Mercerization of Ramie Fibers. Composites Part A: Applied Science and Manufacturing, 37, 2213-2220. http://dx.doi.org/10.1016/j.compositesa.2005.12.014

[21] Al Maadeed, M.A. and Khanam, P.N. (2014) Improvement of Ternary Recycled Polymer Blend Reinforced with Date Palm Fibre. Materials and Design, 60, 532-539. http://dx.doi.org/10.1016/j.matdes.2014.04.033

[22] Mothé, C.G. and Azevedo, A.D. (2009) Análise Térmica de Materiais. Artliber Editora, São Paulo, 324.

[23] Mothé, C.G. and Araújo, C.R. (2000) Properties of Polyurethane Elastomers and Composites by Thermal Analysis. Thermochimica Acta, 357-358, 321-325. http://dx.doi.org/10.1016/S0040-6031(00)00403-2

\section{Submit or recommend next manuscript to SCIRP and we will provide best service for you:}

Accepting pre-submission inquiries through Email, Facebook, Linkedin, Twitter, etc A wide selection of journals (inclusive of 9 subjects, more than 200 journals)

Providing a 24-hour high-quality service

User-friendly online submission system

Fair and swift peer-review system

Efficient typesetting and proofreading procedure

Display of the result of downloads and visits, as well as the number of cited articles

Maximum dissemination of your research work

Submit your manuscript at: http://papersubmission.scirp.org/ 